Article

\title{
Global IWRM Ideas and Local Context: Studying Narratives in Rural Cambodia
}

\author{
Ching Leong ${ }^{1, *}$ and Farhad Mukhtarov ${ }^{1,2}$ \\ 1 Institute of Water Policy, Lee Kuan Yew School of Public Policy, National University of Singapore, \\ Singapore 259770, Singapore; mukhtarov@iss.nl \\ 2 International Institute of Social Studies, Erasmus University Rotterdam, 2518 AX The Hague, The Netherlands \\ * Correspondence: spplcc@nus.edu.sg; Tel.: +65-9271-9693
}

Received: 23 October 2018; Accepted: 10 November 2018; Published: 13 November 2018

check for updates

\begin{abstract}
This article investigates how the "constructivist turn" in public policy and international political economy informs the interaction of global ideas and local practice in water governance. We use the implementation of ideas associated with Integrated Water Resources Management (IWRM) in the Lower Mekong river basin. This article provides some explanation of the attitudes in the villages in Cambodia due to the Sesan 2 Dam, which would see the relocation of thousands of people, damage fisheries, and inflict high coping costs on villagers. Based on 24 in-depth interviews with villagers, commune heads and local community leaders, we find diverse narratives which transcend the "pro or anti" dam narrative. We find four narrative types-myths, stories, noise and informed opinion, which relate to each other in degrees of social meaning and ideational force. Of these, the first two are more likely to be useful in terms of mobilization and policy-making. This typology provides a framework for analysis of social change in the studied villages and other contexts of policy translation. We should state that these four types are not separate from each other but are linked along two axis which together conscribe the four types of narratives outlined.
\end{abstract}

Keywords: dam; local communities; lived experiences; environmental narratives; Cambodia

\section{Introduction}

A prominent paradox in global water resources governance is the dichotomy between two concepts of "integrated water resources management" (IWRM) [1]. One way to view IWRM is to prioritize integration through planning and infrastructure projects across various sectors that influence water resources, such as irrigation, hydro-power production, recreation and drinking water provision and sanitation [2]. The birthplace of this reading of IWRM can be traced to the conservation movement in the United States of America in the early 20th century and the introduction and spread of multi-purpose dam construction, such as the Hoover Dam [3,4]. The conservation movement was rooted in the comprehensive rational planning approach that spread across many countries in the 20th century, including USA, USSR, Germany, China, and Tanzania, and resulted in large dams, irrigation channels and other big scale infrastructural projects [5-7]. A political scientist of development, James Scott (1998) [5], dubbed this approach as "high modernism ideology", based on state confidence in the ability of science and technology to manage natural resources and social welfare. This approach still continues to inspire political leaders and water practitioners who view IWRM as a largely technocratic tool to integrate water, land, ecosystem, energy and economic development related issues $[4,8,9]$.

Another conception of IWRM, however, is that it builds on many failures of comprehensive rational planning and attempts of humans to master nature, and thus, strives to take into consideration ecosystem protection, long-term adaptation to and mitigation of climate change, and social justice of marginalized groups affected by water policy $[2,10]$. This is a more social and ecological 
reading of IWRM where the possibility of a "win-win-win" among the economic, the social and the environmental is taken for granted. However, the issue of big dams shows that the holy grail of IWRM, the "win-win-win" scenario, is much more problematic in practice than in the theory $[4,11,12]$. Such big dam projects require large numbers of citizens to be moved, often have disastrous ecological consequences, and do not always favor local populations, who, for example, may see electricity generated by dams transferred to other regions $[1,8,13]$. This dichotomy is especially pronounced in the Mekong River Basin, where on one hand, large dams are proposed and being built, often in the name of integrated management of water, land and energy. This results in people being evicted from their ancestral land and resettled within a developmental discourse; on the other, the Mekong River Commission as well as individual member-states have worked to emphasize the need for water and food security, which are threatened by the dams, and to promote IWRM in the region [14,15].

This schizophrenic nature of IWRM presents empirical dilemmas to researchers striving to understand how the contradictory visions of IWRM may co-exist in the same space. Many riparian countries have drawn up IWRM plans, with commitments to the protection of the environment [16]. At the same time, they continue to regard economic development and the prosperity of their peoples as being vital. There is a need therefore to understand how these two discourses, and the practices they sanction, co-exist in the Mekong region at the national and local levels. With this paper, we do so at the local level in the case of a dam site in rural Cambodia where the global discourses of development and environmental preservation meet the local realities. Our goal is to understand which of these two interpretations of IWRM is most supported or opposed in our research site, and why.

Theoretically, we build on the idea of "contact zones" as used in post-colonial studies [17,18]. Pratt [17] defines "contact zones" as "social spaces where cultures meet, clash, and grapple with each other, often in contexts of highly asymmetrical relations of power, such as colonialism, slavery, or their aftermaths ..." ". According to her, the asymmetries of power and crude force do not explain fully the variegated experiences of the interaction between various ways of knowing and being, and are not determinant of the ensuing social order. For us, various sites where international discourses, ideas, and capital come in contact with national and local discourses, values, and ways of being to constitute the "contact zones" and the body of literature which studies policy mobility and translations can be of use in making sense of these "contact zones" and the nature of interaction in certain sites [19-21]. What is special in such a relationship is the "interactive, improvisational character of colonial encounters so easily ignored or suppressed by diffusionist accounts of conquest and domination" [17] (p. 4). The contingent, often unexpected and variegated ways in which the global meets the local in the context of IWRM is what interests us in this article.

As Benson and Jordan [22] mentioned, such an emergent and fluid view of "policy in the making" is at odds with more conventional and formulaic approaches of policy design, policy implementation or theories of policy diffusion, policy transfer and learning [22-24]. Instead, "policy mobility and translation" as an approach in policy studies, looks at policy movement in a manner that resists attempts to theorize it through various macro-level structures and explanations, and views the ensuing policy process as a micro-political process which is context specific, interactive, improvisational and contingent $[21,25,26]$. The ideas of policy translation and "contact zones" provide us with the conceptual tools to make sense of how the global and the local interact, and to argue that narratives may be a well-suited tool to understand such interactions.

We draw from a constructivist view of international political economy (IPE), especially in the form offered by Abdelal, Blyth and Parsons [27]. As they contend, "(t) he central insight of constructivism is that collectively held ideas shape the social, economic, and political world in which we live" [27]. In charting their notion of a constructivist IPE, the authors propose four paths to consider. These are (a) the path of meaning; (b) the path of cognition; (c) the path of subjectivity; and (d) the path of uncertainty. We build on these four categories of a constructivist IPE in order to offer an account of how international policy discourses and material interests manifest themselves on the ground and make impact in the Mekong region. More specifically, we bring in a case study of the Sesan 2 Dam in 
Cambodia in order to illustrate our key points and offer a view on how IPE may relate to public policy in the case of the environment.

Our paper is organized as follows, Section 2 presents our treatment of approaches to study how the global and the local intersect, and introduces a discussion of policy translation, "contact zones" and a significant modification of the four paths of a constructivist IPE advanced by Abdelal et al. [27]—from four distinct types into a two-by-two matrix, which sees each type in relation to the others, as well as a continuum of pairs. Here, we present our framework for studying the "contact zones", and a discussion of our methodological choices of ethnographically informed "lived experiences". In Section 3 we introduce our case study in rural Cambodia where the Sesan 2 Dam has been proposed. Section 4 presents our analysis and discussion of data from interviews with the villagers on the way they experience the global ideas on the ground. Finally, Section 5 summarizes and concludes the paper.

\section{The March of Constructivism in Politics}

In this section we discuss how constructivist ideas have shaped both public policy studies and IPE in the recent decades. Our goal is to provide some similarities in the way one may approach these two disciplines which are usually discussed separately and have conventionally been homes to communities which rarely intersect. We first discuss interpretive policy analysis and especially the role of narrative analysis in it, and then move on to discuss the constructivist notions of IPE.

\subsection{Interpretive Policy Studies and Narratives}

The interaction between constructivism and policy studies have been growing over the past decade [28-32]. In empirical investigations, these have ranged from regulation [33], to poverty [34], the role of science in public policy [35] and water management [36-40]. Since the early 2000s, there are also a number of key volumes which define and clearly distinguish interpretive policy analysis from other forms of policy analysis, such as Deborah Stone's "Policy Paradox: The Art of Political Decision-Making" [41], Frank Fischer's "Reframing Public Policy: Discursive Politics and Deliberative Practices" [42], and Peregrine Schwartz-Shea and Dvora Yanow's "Interpretive Research Design: Concepts and Processes" [43].

Arguments for constructivism within policy studies can be examined in two broad strands. First, the epistemological critique which takes issue with the fact that the only legitimate units of analyses in the production of knowledge are limited to observable behavior [44-47]. For these scholars, the positivist, empirical-scientific conception of the policy sciences fails to give a good account of what goes on in government and public policy more broadly [48]. For example, Dryzek observes that "generalization in social science is a chimera, as all situations are different" [48] (p. 310). He and other advocates of interpretive policy analysis suggest that we should look instead to interpretation and perceptions of a constructed reality in the process of policy making [43]. The "interpretive turn" in social sciences in the late 1970s and 1980s [49] was soon joined by others who argue for a hermeneutic approach to social sciences [50].

This approach prioritizes attention that an analyst gives to a policy narrative. Proponents of the narrative approach recognize that information is transformed both in its production and its use, that is to say, how people construct and communicate reality [50-52]. A field of narrative policy analysis has indeed been in formation since the publication of Roe's book [53] on the subject. Furthermore, Feldman et al. [28] speak about how narrative analysis benefits the study of public administration by allowing researchers to examine the "unstated, implicit understandings that underlie the stories people tell" (p. 147).

From the lens of these scholars of narratives, reality is a composite of empirical facts, values and other factors such as history, emotions and social context; all coalescing into a policy story. From this, we infer that a change in narrative would be a push towards policy change, or at least accompanies such a change. 
The second strand of scholarly attention concerns itself with the notion of objectivity in constructivism. Ricouer [54] says that a narrative has an objective meaning that can be "constructed in various ways". He notes that, in a public discourse, the problems of right understanding can no longer be solved by a simple return to the alleged intention of the author [54] but must be construed by a process. "A text has to be construed because it is not a mere sequence of sentences, all on an equal footing, and separately understandable. A text is a whole, a totality" [54] (p. 158).

For Fisher, a collection of such understandings qualifies as "knowledge" which he thinks ought to be expanded "beyond the narrow confines of observational statements and logical proof to include an understanding of the ways people are embedded in the wider social contexts of situation and society" [55] (p. 179). Understanding policy change therefore requires us to take a thick description approach to depicting reality [56]. Fisher [55] (p. 108) furthermore writes: "(t) he key to explaining how change comes about has to be grounded in a detailed contextual examination of the circumstances at play in specific cases. For this purpose, quantitative methods have to take a back seat to qualitative research." This follows the broad field of "interpretative policy analysis" advocated by such thinkers as Yanow [32] and Schwartz-Shea and Yanow [43].

Further to this epistemological thread, Lejano and Ingram [57] argued that narratives form new knowledge, which is different from the objective, value-neutral paradigm of scientific knowledge, but not divorced from it. Such "narrative knowledge" [57] (p. 62) is produced whenever we translate complex, technical or scientific knowledge into everyday ways of knowing-integrated with our beliefs, emotions, history and identities into a coherent and meaningful whole $[58,59]$.

\subsection{Interpretive Turn and International Political Economy}

The interpretive turn has also reached IPE which concerns itself with global issues. The constructivist notion of IPE has been developed to oppose material interests and political power as the major, non-exclusive, explanatory frameworks for international politics and global world order. Among many proponents of taking ideas, norms and discourses seriously in IPE, Barnett and Finnemore [60-62], and more recently Blyth [63] and Abdelal et al. [27] have argued for change in theoretical approaches.

Abdelal et al. [27] outlined four paths that such scholars may follow-the path of meaning, cognition, subjectivity and uncertainty. First, the path of meaning which calls attention to the politics of knowledge, and how policy actors construct meaning in the process of appropriating international discourses within a particular geographic or political locale. Notably, the view of international norms has emerged as key to this approach to political economy as "international norms define the boundaries of choice and thereby affect how societies, policymakers, and market participants discern the meaning of various policy stances" [27] (p. 9).

This type of research looks into how international organizations set norms to member-states and by this means define the boundaries of what is legitimate [60]. It also looks at how international organizations become "norms entrepreneurs" by pushing particular meanings on states and non-state actors, most notably, Transparency International and Freedom House rankings in pressuring states to fight corruption and institute "good governance" [64]. Framing the politics of norms and discursive contestations around the notion of legitimacy are all parts of this type of analysis [27] (p. 16).

The second is path of cognition which calls attention to the taken-for-granted assumptions in policy design and implementation, but also challenges the dominant role of rational choice and technocratic measures in decision-making [65]. Here, scholars are interested in extra-cognitive influences on the way humans construct their worlds, assign meanings to social processes and make polices as a result. This literature looks at the role of emotions, values, affect, and performativity $[1,66]$, and is a growing strand in interpretive policy analysis, which may also be applied to IPE in this regard.

The third is the path of subjectivity, which stresses the importance of the structures and forms that allow for pluralism and multiple ways of knowing in discussing what counts for "reality" and "truth". Here, the major attention is drawn to how international discourses are created to constitute 
actors and define what is "thinkable" or not [27] (p. 14). A good example is Epstein's [67] analysis of the anti-whaling regime, which managed to persist in the presence of scientific data that whales are not endangered and could be safely hunted. Thus, there is a dialectic relationship between agency and structure in this type of work, agents work on defining norms and discourses, which once they become dominant, constitute agents and their preferences, which in turn "reproduce or incrementally shift structures" [27] (p. 14).

Finally, the fourth is the path of uncertainty and unpredictability of policy, and the basic dilemma it poses-how can institutional design happen in the face of inherent unpredictability and contextual sensitivity of social practices? In this strand, the very notion of social reality is cast as emergent and contingent. In economic research, Keynes [68] was among the first to argue that the world is too complex for economic models to have the predictive power, and in IPE such scholars as Blyth $[69,70]$ have taken these ideas further. As we will see in the next subsection, this is one of the key tenets of the "policy mobility and translation" school of public policy.

Drawing on these four paths, researchers of constructivist IPE reconceive how international developments take place $[27,43]$. Here, neither structure nor agency are privileged, but the dialectical relationship between the two illuminates the on-going process of contestation and fixings of ontologies (or reality). The result of our theoretical expositions is a typological modification of Abdelal et al. [27] in relation to the "contact zones" to fit it to our field explorations.

\subsection{Analytical Matrix for Exploring the Global and the Local}

In this, we conceive of the four paths of constructivism as two pairs along two continuums rather than four isolated types. First, within our narrative framework, one pair of contrast is between meaning and subjectivity. Meaning, we conceive of as essentially social, where the meaning is established by its relationship to others. This idea takes bearing from Saussure [71] where language is the result of a link between a signifier (words or images) with a signified (i.e., the concept). There is no "value" or specific meaning resulting from the mere linking of signifier and signified; instead meaning only emerges in relationships with other signs in the language-system. Hence, narratives are said to be meaningful in relationship to other narratives held by people in the community [57]. This stands in contrast to a subjective, a solipsistic conception of what the person feels without reference to social conditions, or others in the community.

Statements in the latter tend to be self-referential. The other pair of paths is an uncertainty and cognition continuum - high cognition means informative statements that weave different empirical facts together in a coherent whole and display high understanding of state of affairs. Uncertainty is the opposite-characterized by many doubts, gaps in knowledge, fears, or emotional reactions that may not be warranted by the objective state of affairs.

With this, we construct a simple matrix - on the horizontal axis, an ideational force with which the "reality" is constructed through the prominent discourses, and where narratives have either strong or weak power of persuasion. On the vertical axis, the degree of social meanings, of how subjects make sense of the changing role of water, hydropower and the impact of dams. Here, "meaning" captures the collective nature of social meanings or ways of knowing, and "subjectivity" captures the phenomenological aspect of our interest-the lived experience of farmers and local communities.

In attempting to understand how various agents construct the narratives around the dam, we will tease out the differences among those two axes. In the next section, we discuss the case study site in rural Cambodia, the policy proposal to build a dam on the tributary to the Mekong River, and our methodological choices in this study. The conceptual framework we have suggested above would come together with the empirical data outlined in Section 3 and inform our major discussion below in Section 4 . 


\section{Case Study and Methodological Choices: Sesan 2 Dam in Cambodia}

Cambodia's Gross Domestic Product (GDP) per capita has tripled between 1999 and 2013. Along with this growth, comes rising demand for electricity-at the rate of $17.9 \%$ annually from 2012 to 2020. Cambodia is projected to grow to nearly 16 million within the next few years, with $80 \%$ of the population living in rural areas. The country's capital Phnom Penh consumes $90 \%$ of its total electricity [72].

Currently, most of Cambodia's electricity demand is met by imported electricity from Vietnam, Thailand and Laos, as well as locally-produced oil generators. High reliance on imported fossil fuels and electricity, lack of electricity in rural regions, and escalating energy demands are challenges being faced by the Cambodian government. Against such a backdrop, hydropower projects appear attractive as a means of producing clean energy while catering to the overall economic development of the region. About 80\% of over 60 million people living along the Lower Mekong Basin rely on the river for livelihood, food, socio-economic activities and other ecological services. The lower Mekong River includes Sesan and Srepok, two tributaries of the Mekong.

Our research site is along the Sesan River which flows through Central Vietnam and northeast Cambodia, in the province of Stueng Treng. In November 2012, a 400-megawatt dam, the Lower Sesan 2 (LS2) dam project, was started with an investment of US \$816 million. The company is formed with a majority stake from China's Hydrolancang International Energy and Cambodia's Royal Group. Most of the electricity will be sold to state energy provider Electricite Du Cambodge (EDC) or exported to Vietnam under a 40-year contract [73].

A 2012 study [74] by US and Cambodian researchers estimated that the dam, once constructed, will deplete fish biomass (due to fish migration blockage) in both Sesan and Sreypok, by more than 9\%. Experts have also warned that the LS2 dam might significantly change the hydrology of Mekong River and Cambodia's Tonle Sap Lake, while diminishing sediment flows to the Mekong Delta.

The Rivers Coalition in Cambodia, a group of non-governmental organizations (NGOs), have reported the dam reservoir is set to flood more than 30,000 ha, most of which is forest area including some 1200 ha of community farmland and housings. As a result, illegal logging in the affected forests has significantly gone up. A few active NGOs in Cambodia have challenged the government's evaluations of the complications arising from the LS2. They have argued for more open discussions between the government and civil society groups, including non-government organizations and civic leaders [72].

The 2009 Environmental Impact Assessment (EIA) shows that the dam project will displace nearly 5000 villagers in about 1100 households from seven villages in four communes. However, the 2009 report points out that the impacts might be much worse than predicted in the EIA. Villagers who live along the Sesan and Srepok Rivers upstream of the LS2 as well as 87 villages of the tributaries of the two rivers, will lose access to migratory fish. The same research also found that over 22,000 villagers living downstream from LS2 would be negatively impacted as a result of changes in river hydrology and water quality [73]. The 24 villagers interviewed come from three affected villages (Sreh Kor 2, Plork, and Kbal Romeas, where Sreh Kor 2 is upstream and Kbal Romeas is downstream). The location of these villages is indicated in Figure 1 below. The interviews were conducted over three days, from 11-13 August 2015. The three villages shared the following characteristics-there were many medium income households (except for Sreh Kor village where households appear to be more well off than the rest of the villages). All the villagers were highly dependent on river water for both drinking and daily usage. The villagers typically worked as rice farmers, non-rice farmers, and fishermen. Importantly, for our study of constructivism and narratives, the households are situated near to one another so that the flow of information is good and community meetings are frequent. We have not pursued a comparison across villages and did not therefore code utterances by interviewees in accordance with the village they come from. While the names of the interviewees are known to authors, because of requested anonymity we do not provide any references to the authors of 
quotes. Instead, we categorize these quotes in the four categories we have devised and count these in order to understand the comparative spread of these types in our sample.

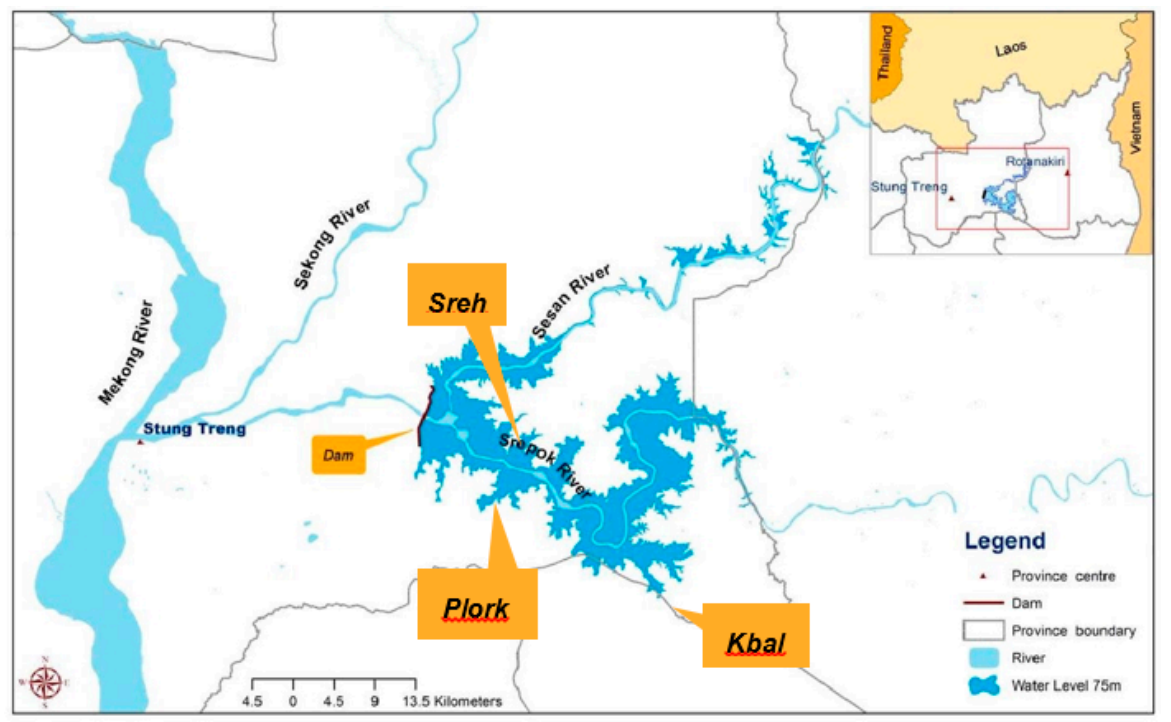

Figure 1. Map and location where fieldwork took place. Source: The map was retrieved from CDRI (Cambodia Development Resource Institute), Theavy Chom.

The lived experience method was operationalized with an interview guide (see Appendix A) along three themes, namely (1) Everyday Use of Mekong River, (2) Hydropower Dam and (3) Perceived Participation. The breakdown of interviews in Sreh Kor 2 (11 August 2015), Plork (12 August 2015), and Kbal Romeas (13 August 2015) is as in Table 1. The interview guide is presented in Appendix A.

Table 1. The matrix of social construction of international political economy (IPE). Based on Abdelal et al. [14].

\begin{tabular}{|c|c|c|c|}
\hline \multirow{6}{*}{$\begin{array}{l}\text { Degrees of } \\
\text { Social } \\
\text { Meaning }\end{array}$} & & \multicolumn{2}{|c|}{ Ideational Force } \\
\hline & & Uncertainty & Cognition \\
\hline & \multirow[t]{2}{*}{ Meaning } & $\begin{array}{l}\text { I feel afraid, that life will be more } \\
\text { difficult. When they construct the dam, } \\
\text { they will close the big river and they } \\
\text { will create the new small one. I forgot } \\
\text { how I got this information. }\end{array}$ & $\begin{array}{l}\text { I worry a lot. I am afraid that when we go } \\
\text { to new land, it won't be as good as the old } \\
\text { place. Second, I am afraid that the land } \\
\text { cannot be farmed. I do not know that kind } \\
\text { of land. We grow rice, we harvest rice. We } \\
\text { plant fruits, we collect fruits. We worry. } \\
\text { New land is not the same as old land. }\end{array}$ \\
\hline & & Q1 (Myths) & Q2 (Stories) \\
\hline & \multirow[t]{2}{*}{ Subjectivity } & $\begin{array}{l}\text { The river gives us fish and water. As } \\
\text { water is unclear, we have to adapt to } \\
\text { that. }\end{array}$ & $\begin{array}{c}\text { Yes, there are benefits. I think we cannot } \\
\text { win (to stop the dam). They (NGOs) can } \\
\text { just explain things to us. We understand } \\
\text { but we cannot do anything. We protested } \\
\text { several times, but they do not care about us. } \\
\text { They do not "take their ear" to listen and } \\
\text { they walk away. }\end{array}$ \\
\hline & & Q3 (Noise) & Q4 (Informed Opinions) \\
\hline
\end{tabular}

We base our research on the method of "lived experiences", which has its roots in ethnographic methodology and phenomenology [75]. We are interested in the storylines that local residents have with regard to resettlement (e.g., Rousseau [76]). Here, we are not interested in gaining information from our research subjects based on the concepts or codes which we have designed a priori, but allow for those ideas to emerge from the fieldwork, in terms and meanings experienced and formed by the researched themselves [57]. This is closely related to ethnography as a research methodology [77]. Ethnography can be defined as "a family of methods involving direct and sustained social contact with 
agents, and of richly writing up the encounter, respecting, recording, and representing at least partly in its own terms, the irreducibility of human experience" [78] (p. 5). Narrative is a unit of analysis in this research as it allows to understand the reasoning of people which may otherwise appear senseless or difficult to explain [79].

The contemporary forms of ethnography have been called "ethnography-lite" as the world is increasingly inter-related and on the move [20,80]. Kubik [81] speaks of "ethnographic sensitivities" where ethnography is global and multi-sited. We follow in the steps of these scholars, but limit ourselves to the "lived experiences" at the local level for this study. As our major point with this article is to discuss how IPE and public policy inform each other through the use of narratives and "contact zones", our case has an illustrative power.

With regard to how we operationalized this method, we do not claim that each statement constitutes a "narrative" but rather how such a statement, together with other similar, stands for a certain narrative type. Of course, individuals can hold beliefs across different narrative types, and such beliefs can change over time; and indeed, the momentum and pervasiveness of such beliefs have great impact on how local narratives regarding development and dams are constructed.

A more detailed multi-sited ethnography and policy interviews with other actors involved in the construction of Sesan 2 Dam as well as the stakeholders at the national and transnational levels would be useful for an extensive "political ethnography" of this project. This, unfortunately, is beyond the scope of this article.

\section{Discussion: Narrative Types}

As a result of coding the interview transcripts, we identified four categories present in the field: "Myths", "stories", "informed opinions", and "noise". Each category has attributes which vary across two scales: The extent to which a narrative is shared among community members, and the extent to which it is consistent and coherent as well as powerful in making a point. We discuss each of these categories below with quotes from the transcripts.

\subsection{Noise}

On the weaker end, noise is what we call fragmented narratives, uncertain in factual origin and not embedded in any social norm or view. They are often transient and uncertain in origin and emotional in content. Narratives here are often not fully formed. Here are a few examples of noise from our fieldwork site:

"This is because, I also don't know, but I heard from others that it is because they construct a dam at the end of the river."

"I don't know what to do next. I don't really have experience what to do besides doing farming and raising fish."

"We have no fish anymore, so what should we do? That's why we should raise the fish. I have no experience, but I have to learn. If everyone raises, I will follow them."

"So, we do not dare to say if their suggestion (proposing compensation) is cheap or expensive. We do not want to leave our home. Our house is not cheap to build. Who wants to leave? Even if you have a boat, do you think you can take me and my husband? No, you cannot take us. We cannot live on the river. Only Yuon (Vietnamese) build houseboats to live on water. We cannot. Khmer and minority do not build house on water (river, lake)."

These quotations indicate much confusion and fragmentation in terms of bits and pieces of information, often invalidated, which are not yet well shaped into a narrative, of such a narrative is, these are fragmented and poorly articulated. 


\subsection{Myths}

Myths are powerful, but they may lack full grounding in fact. They tend to appear in situations when information is scarce, and no clear communication is provided. In our case, they occur in a number of areas, such as resettlement, water quality for drinking, fishing and the possibility of markets opening up in places with hitherto available water. Below are some quotes from our interviews which indicate that such myths lack clarity and are shared among multiple actors. Here, it is important to note that we use the term "myth" in order to signify a story which does not rely on factual information but is told in a cohesive manner nevertheless. We realize that the study of myths in social sciences is rich in various approaches (e.g., de Guevara [82]), and qualify our use of the term "myth" in that particular fashion.

"Water is public use since it is available all the time so there is no complaint about the shortage of water and we also do not have to buy it. But the quality of water from the river is not good because there is Yali dam construction in Vietnam. The quality of water has changed since 2001. In the beginning, I didn't know the dam project but just noticed that during dry season water levels had suddenly dropped and boats disappeared. Before 1999, people could use water for direct drinking but now we have to boil it."

The passage above shows that the resident has made sense of the change and has a cause-effect model to link the dam with adverse effects on water quality and quantity. However, there is much uncertainty about the future and possible ways to deal with the situation.

Another example of a myth-like statement is this: "I am afraid that life will be more difficult. When they construct the dam, they will close the big river and they will create only the new small one. I forgot how I got this information".

This quotation from an interview with a farmer indicates that there is little clarity, and gaps in information in terms of the future plans of the government and possible impacts of these on the river. In such uncertainty, multiple narratives and myths appear.

The following two passages further illustrate little certainty about the future, and thus confusion among people who are not sure whom to believe or what to expect. Such uncertainty is unsettling and does not contribute to trust in government or between citizens.

"According to them (government officials), not much land will be flooded. But those who campaign against the dam says there will be a big flood. It is hard to decide. People say that the waters will reach a height of $5 \mathrm{~m}$. If so, it will flood the house. Others say water will not reach $5 \mathrm{~m} . "$

"I don't know. I'm just worried that water will be contaminated and there will be lack of water. Now the dam is still opened, but if it is blocked, the tree branches or its roots will be rotten and drop to the river that will be hard to consume. That is the point."

\subsection{Informed Opinions}

Opinions have a stronger footing in fact. However, there is little sense of a shared understanding, or of looking at interests in a collective manner. Here are some examples of informed opinions of farmers and villagers. These are much better articulated than the myths or noise, but are not as widely shared as stories are. They are pronounced from a singular perspective and have consistency and clarity to their narrative.

"I used to join the meeting twice with the dam representative. And I try to raise the issue, but the price is still kept the same as original. The chief of the village has also complained to the provincial department, but they still use the original plan."

"To my family, this Sur San River provides a lot of benefits to me. Along the river side, the vegetable is plentiful there. The fish is also available. The environment is clean as well. In contrast, it has been changing now." 
"I did not get it. People who live at the down side there is no compensation. However, for those live at the upstream side they had. Three persons from the upstream dam didn't get compensation yet. I also have land there, but it is far from dam."

"To me, people should negotiate through the local authority because they are more powerful and because they have meetings, public forum. When they say in this meeting, their suggestions will be recorded in the minutes of meeting. They, most of the time, complain the company through organizations. The company makes excuse that people are against the development project. The company is careless with the people. Right?"

\subsection{Stories}

Unlike myths and noise, stories are high in cognition and social meaning, and have a strong outward-looking, other-regarding component, rooted as well in different empirical facts which are more established than the case with the myths. Below are a few examples of these.

“The government should bring the compensation book and consult with people (villagers). People should be involved in determining or setting the price of that compensation. This is done in order to know whether people agree or not first."

"I worry a lot. I am afraid that when go to new land is not good as old place. Second, I am afraid that the land cannot be farmed. I do not know the kind of land. We grow rice, we get rice. We plant any fruits, and we get the results. We worry. New land may not be the same as old land."

These quotations underpin uncertainty, but with a more articulated position from the respondent in terms of advocacy, what is right or wrong and how they could possibly act upon these. Stories are also riddled with emotions, values and morality claims, for example:

"Advantage is we can have electricity country wide, and even sell it to outside the country.

However, we cannot conclude it until there will be result we can see."

This suggests a lack of trust in government and in people reporting deviant behavior. At the same time, there is a stronger sense of social justice in the statement below:

"I think that river is a property for all, not for people, or government. It is a property for all. We have to help each other to protect the river, like protect not to have illegal fishing, take care of fish. We must cooperate to protect it."

Stories are the most articulated and widely shared form of narratives and have much in common with advocacy in a sense that they solidify the framing, actors and cause-effect relationships. By such explicit framing, these stories are most likely to gain support of other villagers and develop into a social movement with clear advocacy implications.

\section{Conclusions}

In this paper, we looked at how local populations in three villages in rural Cambodia, namely Sreh, Plark, and Kbal Romeas have experienced the proposal to build a large hydropower dam in the vicinity of their villages, which reflects the global trend of displacement and increased construction of dams in the South-East Asia often framed in the language of IWRM [8].

The environmental impact assessment showed a number of impacts on their livelihoods, such as the inundation of land, the impact on fisheries and the need for about 2000 people across a number of villages to leave their ancestral lands. With regard to this, we have concerned ourselves with the "lived experiences" of villagers in their everyday life and dependence on the Mekong River.

Theoretically, we have conceptualized these three villages as the sites of "contact zones" where the global push for development comes into contact with the local reality of everyday life and cultivation of rice, fisheries and other economic activities. We are interested in exploring the narratives 
advanced by our interviewees and making a distinction between strong and weak narratives on one continuum, and confusion and opinion on the other. To help make sense of the narratives from the field, we modified the typology of Abdelal et al. [27] and put forward a $2 \times 2$ matrix for classifying narratives.

The four types which we identified are: Myths, stories, noise and informed opinion. Of these, the first two are more likely to be useful in terms of mobilization and policy-making, given that the latter then to be more self-regarding. However, the four quadrants are linked, as narratives evolve from one form to another.

One contribution of our article is to argue that the four paths to social construction can be conceived of jointly as part of a simple matrix. We have also used an empirical test to show how narratives in a certain case can fall into each of these quadrants and how the narratives and discourses in each quadrant differ from one another.

We have argued that stories are strong narratives-coherent and with a strong causal progression, with delineated objects and subjects and causes. These also are socially shared and not individually perceived. Myths are moderately strong narratives, but with a less solid grounding in coherence with external, objective factors. Weak narratives are not socially shared and hence lack the strength of persuasion and richness which the strong narratives have. When a respondent has expressed confusion and uncertainty about the situation, often in terms of fear and lack of control, and when such sentiment has been stated for him or her individually, we have coded this as "noise"-a concern which however is not yet developed into a narrative.

When actors have stated their ideas in a more coherent fashion, presenting causal stories which however were not clearly shared among community members, we coded these as "informed opinion." While the latter may be useful for individual action, the former are poor guides for collective action, for which only strong narratives are useful.

As a result of our study, we found that the anti-dam sentiment among the interviewed villagers is the strongest, and hence gives rise to strong narrative of resistance to the dam and preservation of their land and habitual lifestyles ( 88 references to this narrative). However, a narrative which we labeled "weak narrative" comes close in its support. It views the building of the dam as inevitable, and encourages villagers to organize in order to achieve a better compensation and future adaptation to changing life conditions. This narrative is common ( 52 references to it), but it lacks the same symbolic and mobilization power that the anti-dam narrative has, as there are no advocacy groups or NGOs which could strengthen the narrative on behalf of the villagers.

A number of villagers expressed high confusion and helplessness with regard to coming changes (62 references to it), and some others have been clear on how to change things towards better, but not certain if this is achievable (64 references to it). Overall, the two narratives can be discerned from the interviews-a strong "anti-dam" narrative and a weaker "adaptation and accommodation" narrative. Interestingly, we found no evidence of support to the dam despite the presence of compensation for resettlement process as well as the strong support from Cambodian NGOs advocating for resettlement on behalf of villagers to secure the best deal [83].

We found that strong narratives are most visible in the field, but not necessarily the most legitimate, or most widely shared ones. We also found that many ideas and opinions stated individually have the potential of developing into strong narratives. What we are not able to explain at this stage, however, is what makes this shift possible, from weak narratives to strong ones, and from confusion and opinion to weak and strong narratives. It seems to us that these are based on strong leadership, on the open forum for deliberation and discussion, social capital and trust in a community, and possibly the presence of skilled intermediaries, or translators/narrators, who could add symbolic and political power to narratives by making it richer and more authentic. Such leadership may emerge from villagers themselves, but is more likely to originate from national NGOs and advocacy groups that seek to represent villagers at higher levels of governance and fora where the dam is discussed. Baird (2016) [83], in the context of the Sesan 2 dam, raised a possibility that NGOs may pursue some of their own goals in representing villagers in higher level governance fora. If these concerns are grounded, it is important 
to understand whether such NGOs first need to create a uniformity of narratives among villagers to rally their support and acquire authority to represent them. Such uniformity is apparently lacking in the villages that we studied-to the opposite, some are ready to fight the dam until last resources, while others prefer to focus on negotiating the best deal for compensation, and the third group remains unorganized and confused. This diversity of experiences enriches the accounts of anti-dam sentiments described by Baird (2016) [83] in the case of the Sesan 2 dam, and other scholars in other dam sites $[8,84,85]$. Future research should throw light on the extent to which such narrative diversity is an impediment for successful advocacy.

Returning to the major subject of this article, the role of IWRM in the cases of dam-driven development projects, it seems to us that the two incompatible notions of IWRM represent meta-narratives that adversarial parties use to mobilize support in their political struggle. IWRM, however, plays no role at all in the language of villagers. This indicates at a discursive, rather than pragmatic nature of IWRM in this case study; IWRM is a tool to achieve political goals by opposing parties in the conflict around the Sesan 2 dam. Instead of IWRM, studying local narrative types helps understand how such higher level political struggles may develop, but is also important to register lived experiences of those most impacted by the dam, how such experiences get mobilized into anti-dam advocacy and by whom.

This paper thus provides a finishing piece in the move towards adaptive management and IWRM, with the recognition that water governance requires not just the technical management of water but an integration of the human dimension $[86,87]$.

In the case of water management, the notion of "adaptive capacity" has become a necessary component of IWRM, with the need to ensure that designs of water management systems allow the incorporation of new socio-technical systems, the building of social capital in an actor network and restoring multi-functional landscapes [88]. Researchers in the past have argued that local participation provides the best platform of creative adaptation to local context [89].

Given this, the "lived experiences" of locals, with their knowledge of historical development, the physical characteristics of the basin, and other contextual factors, greatly affects how river basin organizations are formed, how they change over time and the functions they perform. Therefore, while this investigation takes places at a granular, local level, it has important implications for how national narratives form and hence how transboundary cooperation can succeed, or fail, as political pressures coalesce around local concerns.

Author Contributions: Conceptualization, F.M. and C.L.; Methodology, C.L.; Software, C.L.; Validation, C.L.; Formal Analysis, F.M. and C.L.; Investigation, C.L.; Resources, C.L.; Data Curation, C.L.; Writing-Original Draft Preparation, F.M. and C.L.; Writing-Review \& Editing, F.M and C.L.; Project Administration, C.L.; Funding Acquisition, C.L.

Funding: This research received funding from CGIAR.

Acknowledgments: The writers acknowledge the research assistance of Phaloeuk Kong and Tan Ting Yu.

Conflicts of Interest: The authors declare no conflicts of interest.

\section{Appendix A. Detailed Interview Guide}

A detailed interview guide was established with questions revolving around three themes:

(1) Everyday Use of Mekong River

(2) The building of the Hydropower Dam

(3) Perceptions of Participation.

The themes are developed in order to formulate the "Local definition of Good Governance in Mekong River". The research aims at identifying related priorities, including those associated with the particular needs of women, the equitable sharing of benefits of river development, and the meaningful accounting of ecosystem services. 
The research questions were then translated into local dialects and the interviews briefed on these. The questions are guides, and some of the respondents veered away from these-we recorded these and coded their own responses.

Interview Questions

Everyday Use of Mekong River

1. How would you describe your use of Mekong River or Se San River? What is the most important thing of Mekong River that you use?

2. How is Mekong River part and parcel of your everyday life and why?

3. According to your everyday experience, have you noticed any change in Mekong River? What are the changes? What do you think are the causes of the changes?

\section{Hydropower Dam}

1. Do you know about the development of Lower Se San 2 Dam or Ya Li Dam in Vietnam? How do you feel about it?

2. How would your life change, or be affected after the hydropower is constructed?

3. If affected, do you receive any compensation from the government or developer? What are they?

4. Have you experienced any water related disasters like flood and drought? Why did they happen? How did it affect your life? What do you think should be done?

\section{Participation}

1. How does the government engage you and community in the development of hydropower? Why?

2. Have you ever provided any suggestion to the authority on the development of dam? Was it effective? Was it accepted? Why?

3. Have you ever been involved in any activities to protect the river and environment? Why did you do it?

4. Are there a lot of women participating in those activities? Why did they participate?

5. What are the skills that you think you need to improve your activities in protecting the environment of Mekong River?

6. How should the government govern Mekong River? Why?

7. What do you think your community should do to protect the environment of Mekong River?

8. Looking ahead, what are some of the most urgent issues that we should be considering in terms of Mekong River?

\section{References}

1. Mukhtarov, F.; Gerlak, A.K. Epistemic forms of integrated water resources management: Towards knowledge versatility. Policy Sci. 2014, 47, 101-120. [CrossRef]

2. Global Water Partnership. Integrated Water Resources Management; TAC Background Papers, No. 4; Global Water Partnership: Stockholm, Sweden, 2000.

3. Hays, S.P. Conservation and the Gospel of Efficiency; Harvard University Press: Cambridge, MA, USA, 1959.

4. Mukhtarov, F. The hegemony of integrated water resources management: A study of policy translation in England, Turkey and Kazakhstan. In Budapest: Department of Environmental Sciences and Policy; Central European University: Budapest, Hungary, 2009.

5. Scott, J.C. Seeing Like a State: How Certain Schemes to Improve the Human Condition Have Failed; Yale University Press: New Haven, CT, USA, 1998.

6. Josephson, P.R. Industrialized Nature: Brute Force Technology and the Transformation of the Natural World; Island Press: Washington, DC, USA, 2002.

7. Allan, T. IWRM/IWRAM: A New Sanctioned Discourse? Occas. Paper 2003, 50, 1-27. 
8. Conca, K. Governing Water: Contentious Transnational Politics and Global Institution Building; Massachusetts Institute of Technology: London, UK, 2006.

9. Molle, F.; Mollinga, P.P.; Wester, P. Hydraulic bureaucracies and the hydraulic mission: Flows of water, flows of power. Water Altern. 2009, 2, 328-349.

10. UN Environment. Progress on Integrated Water Resources Management: Global Baseline for SDG 6. Indicator 6.5.1: Degree of IWRM Implementation; UN Environment: Nairobi, Kenya, 2018.

11. Biswas, A.K. Integrated water resources management: A reassessment: A water forum contribution. Water Int. 2004, 29, 248-256. [CrossRef]

12. Mollinga, P.P. IWRM in South Asia: A concept looking for a constituency. In Integrated Water Resources Management in South Asia. Global Theory, Emerging Practice and Local Needs; SAGE Publications: California, CA, USA, 2006; Chapter 1; pp. 21-37.

13. Mehtonen, K.; Keskinen, M.; Varis, O. The Mekong: IWRM and institutions. In Management of Transboundary Rivers and Lakes; Springer: Berlin/Heidelberg, Germany, 2008; pp. 207-226.

14. Dore, J.; Lebel, L.; Molle, F. A framework for analysing transboundary water governance complexes, illustrated in the Mekong Region. J. Hydrol. 2012, 446, 23-36. [CrossRef]

15. Gerlak, A.; Mukhtarov, F. Many Faces of Security: Discursive Framing in Cross-border Natural Resource Governance in the Mekong River Commission. Globalizations 2016, 13, 719-740. [CrossRef]

16. Global Water Partnership Annual Report 2009. Available online: https://issuu.com/gwp-publ/docs/gwp_ in_action_-_annual_report_2009 (accessed on 11 October 2018).

17. Pratt, M.L. Imperial Eyes: Travel Writing and Transculturation; Taylor and Francis: Abingdon, UK, 1992.

18. Pratt, M.L. Arts of the Contact Zone. Profession 1999, 91, 33-40.

19. Blaustein, J. Speaking Truths to Power: Policy Ethnography and Police Reform in Bosnia and Herzegovina, 1st ed.; Oxford University Press: Oxford, UK, 2015.

20. Clarke, J.; Bainton, D.; Lendvai, N.; Stubbs, P. Making Policy Move: Towards a Politics of Translation and Assemblage; Policy Press: Cambridge, UK, 2015.

21. Mukhtarov, F. Rethinking the travel of ideas: Policy translation in the water sector. Policy Polit. 2014, 42, 71-88. [CrossRef]

22. Benson, D.; Jordan, A. Policy transfer research: Still evolving, not yet through? Polit. Stud. Rev. 2012, 10, 333-338. [CrossRef]

23. Dolowitz, D.P.; Marsh, D. Learning from abroad: The role of policy transfer in contemporary policy-making. Governance 2000, 13, 5-23. [CrossRef]

24. Doblin, F.; Simmons, B.; Garrett, G. The global diffusion of public policies: Social construction, coercion, competition, or learning? Annu. Rev. Sociol. 2007, 33, 449-472.

25. Freeman, R. Reverb: Policy making in wave form. Environ. Plan. A 2012, 44, 13-20. [CrossRef]

26. Mukhtarov, F.; Daniell, K. Diffusion, adaptation and translation of water policy models across countries. In Oxford Handbook of Water Policy and Politics; Oxford University Press: Oxford, UK, 2016.

27. Abdelal, R.; Blyth, M.; Parsons, C. Constructing the International Economy; Cornell University Press: Ithaca, NY, USA, 2010.

28. Feldman, M.S.; Sköldberg, K.; Brown, R.N.; Horner, D. Making sense of stories: A rhetorical approach to narrative analysis. J. Public Adm. Res. Theory 2004, 14, 147-170. [CrossRef]

29. Hajer, M. Policy without polity? Policy analysis and the institutional void. Policy Sci. 2003, 36, $175-195$. [CrossRef]

30. Hampton, G. Narrative policy analysis and the integration of public involvement in decision making. Policy Sci. 2009, 42, 227-242. [CrossRef]

31. Yanow, D. Silences in public policy discourse: Organizational and policy myths. J. Public Adm. Res. Theory 1992, 2, 299-423.

32. Yanow, D. Interpretation in policy analysis: On methods and practice. Crit. Policy Anal. 2007, 1, 110-122. [CrossRef]

33. Bridgman, T.; Barry, D. Regulation is evil: An application of narrative policy analysis to regulatory debate in New Zealand. Policy Sci. 2002, 35, 141-161. [CrossRef]

34. Cassiman, S.A. Toward a more inclusive poverty knowledge: Traumatological contributions to the poverty discourse. Soc. Policy J. 2006, 4, 93-106. [CrossRef] 
35. Garvin, T.; Eyles, J. The sun safety metanarrative: Translating science into public health discourse. Policy Sci. 1997, 30, 47-70. [CrossRef]

36. Jeffery, P.; Seaton, R.A.F. A Conceptual Model of 'Receptivity' Applied to the Design and Deployment of Water Policy Mechanisms. Environ. Sci. 2004, 1, 277-300. [CrossRef]

37. Moss, T.; Newig, J. Multilevel water governance and problems of scale: Setting the stage for a broader debate. Environ. Manag. 2010, 46, 1-6. [CrossRef] [PubMed]

38. Mukhtarov, F.; Cherp, A. The hegemony of integrated water resources management as a global water discourse. In River Basin Management in the Twenty-First Century; Squires, V.R., Milner, H.M., Daniell, K.A., Eds.; CRC Press: Boca Raton, FL, USA, 2014.

39. Newig, J.; Pahl-Wostl, C.; Sigel, K. The role of public participation in managing uncertainty in the implementation of the Water Framework Directive. Eur. Environ. 2005, 15, 333-343. [CrossRef]

40. Trottier, J. Water crises: Political construction or physical reality? Contemp. Polit. 2008, 14, 197-214. [CrossRef]

41. Stone, D. Policy Paradox: The Art of Political Decision Making, 3rd ed.; W. W. Norton \& Company: New York, NY, USA, 2001.

42. Fischer, F. Reframing Public Policy: Discursive Politics and Deliberative Practices; Oxford University Press: Oxford, UK, 2003.

43. Schwartz-Shea, P.; Yanow, D. Interpretive Research Design: Concepts and Processes; Routledge: London, UK, 2012.

44. Banfield, E. The Unheavenly City: The Nature and Future of Our Urban Crisis; Little Brown and Company: Boston, MA, USA, 1970.

45. Fischer, F. Politics, Values, and Public Policy: The Problem of Methodology; Westview Press: Boulder, CO, USA, 1980.

46. Moynihan, D.P. The professionalization of reform. Public Interest 1965, 1, 6.

47. Schuman, D. Policy Analysis, Education, and Everyday Life: An Empirical Reevaluation of Higher Education in America; D. C. Health: Washington, DC, USA, 1982.

48. Dryzek, J. Policy analysis as a hermeneutic activity. Policy Sci. 1982, 14, 309-329. [CrossRef]

49. Rabinow, P.; Sullivan, W.M. Interpretive Social Science, 2nd ed.; University of California Press: Berkeley, CA, USA, 1985.

50. Lejano, R.P.; Leong, C. A Hermeneutic Approach to Explaining and Understanding Public Controversies. J. Public Adm. Res. Theory 2012, 22, 793-814. [CrossRef]

51. Guba, E.G.; Lincoln, Y.S. Competing paradigms in qualitative research. In Handbook of Qualitative Research; Denzin, N.K., Lincoln, Y.S., Eds.; SAGE Publications: Thousand Oaks, CA, USA, 1994; Volume 2, pp. 105-117.

52. Lin, D. An information-theoretic definition of similarity. ICML 1998, 98, 296-304.

53. Roe, E. Narrative Policy Analysis: Theory and Practice; Duke University Press: Durham, NC, USA, 1994.

54. Ricoeur, P. The model of the text: Meaningful action considered as a text. New Lit. Hist. 1973, 5, 91-117. [CrossRef]

55. Fisher, R.J. Social desirability bias and the validity of indirect questioning. J. Consum. Res. 1993, 20, $303-315$. [CrossRef]

56. Geertz, C. The Interpretation of Cultures; Basic Books: New York, NY, USA, 1973.

57. Lejano, R.P.; Ingram, H. Collaborative networks and new ways of knowing. Environ. Sci. Policy 2009, 12, 654-662. [CrossRef]

58. Polkinghorne, D. Narrative Knowing and the Human Sciences; State University of New York Press: Albany, NY, USA, 1988.

59. Sandelowski, M. Telling stories: Narrative approaches in qualitative research. J. Nurs. Scholarsh. 1991, 23, 161-166. [CrossRef]

60. Barnett, M.; Finnemore, M. Rules for the World: International Organizations in Global Politics; Cornell University Press: Ithaca, NY, USA, 2004.

61. Finnemore, M. National Interests in International Society; Cornell University Press: Ithaca, NY, USA, 1996.

62. Katzenstein, P. The Culture of National Security; Columbia University Press: New York, NY, USA, 1996.

63. Blyth, M. Structures do not come with an Instruction Sheet: Interests, Ideas and Progress in Political Science. Perspect. Polit. 2003, 1, 695-703. [CrossRef]

64. Cox, R. Ethics and Integrity in Public Administration: Concepts and Cases; Routledge: London, UK, 2009. 
65. Kahneman, D.; Slovic, P.; Tversky, A. Judgement under Uncertainty: Heuristics and Biases; Cambridge University Press: Cambridge, UK, 1982.

66. Schneider, A.; Ingram, H. Ways of Knowing: Implications for Public Policy. In Proceedings of the Annual Meeting of the American Political Science Association, Chicago, IL, USA, 29 August-2 September 2007.

67. Epstein, C. Moby Dick or Moby Doll? Discourse, or How to Study the "Social Construction of" All the Way Down. In Constructing the International Economy; Abdelal, R., Blyth, M., Parsons, C., Eds.; Cornell University Press: Ithaca, NY, USA, 2010; pp. 175-194.

68. Keynes, J.M. The general theory of employment. Q. J. Econ. 1937, 51, 209-223. [CrossRef]

69. Blyth, M. Great Punctuations: Prediction, Randomness, and the Evolution of Comparative Political Science. Am. Polit. Sci. Rev. 2006, 100, 493-498. [CrossRef]

70. Blyth, M. Powering, Puzzling, or Persuading? The Mechanisms of Building Institutional Orders. Int. Stud. Q. 2007, 51, 761-777. [CrossRef]

71. Saussure, F.D. Coure in General Linguistics; Philosophical Library: New York, NY, USA, 1959.

72. Rethinking Hydropower: Reflections on the Lower Sesan 2 Dam. The Greater Mekong Blog. Available online: https:/ / wle-mekong.cgiar.org/rethinking-hydropower-reflections-on-the-lower-sesan-2-dam/ (accessed on 11 October 2018).

73. Fact Sheet: Lower Sesan 2 Hydropower Project, Northeastern Cambodia. Available online: http://www. mekongwatch.org/PDF/LS2_FactSheet_ENG_20151110.pdf (accessed on 11 October 2018).

74. Ziv, G.; Baran, E.; Nam, S.; Rodríguez-Iturbe, I.; Levin, S.A. Trading-off fish biodiversity, food security, and hydropower in the Mekong River Basin. Proc. Natl. Acad. Sci. USA 2012, 109, 5609-5614. [CrossRef] [PubMed]

75. Morvant-Roux, S.; Guerin, I.; Roesch, M.; Moisseron, J.Y. Adding value to randomization with qualitative analysis: The case of microcredit in rural Morocco. World Dev. 2014, 56, 302-312. [CrossRef]

76. Rousseau, J.F.; Orange, D.; Habich-Sobiergala, S.; Van Thiet, N. Socialist hydropower governances compared: Dams and resettlement as experienced by Dai and Thai societies from the Sino-Vietnamese borderlands. Reg. Environ. Chang. 2017, 17, 2409-2419. [CrossRef]

77. Pachirat, T. The Political in Political Ethnography: Dispatches from the Kill Floor. In Political Ethnography: What Immersion Contributes to the Study of Power; Schatz, E., Ed.; University of Chicago Press: Chicago, IL, USA, 2009; pp. 143-162.

78. Willis, P.; Trondman, M. Manifesto for Ethnography. Ethnography 2000, 1, 5-16. [CrossRef]

79. Levine, J.; Isaeva, A.; Eddy, I.; Foggin, M.; Gergel, S.; Hegerman, S.; Zeriffi, H. A cognitive approach to the post-Soviet Central Asian pasture puzzle: New data from Kyrgyzstan. Reg. Environ. Chang. 2017, 17, 941-947. [CrossRef]

80. Schatz, E. Political Ethnography: What Immersion Contributes to the Study of Power; Chicago University Press: Chicago, IL, USA, 2009.

81. Kubik, J. Ethnography of politics: Foundations, applications, prospects. In Political Ethnography: What Immersion Contributes to the Study of Power; Schatz, E., Ed.; Chicago University Press: Chicago, IL, USA, 2009.

82. De Guavara, B. Myth and Narrative in International Politics; Palgrave MacMillan: London, UK, 2016.

83. Baird, I.G. Non-government Organizations, Villagers, Political Culture and the Lower Sesan 2 Dam in Northeastern Cambodia. Crit. Asian Stud. 2016, 48, 257-277. [CrossRef]

84. Roy, A. Greater Common Good. Friends of the River Narmada. Available online: www.narmada.org (accessed on 2 November 1999).

85. Nelson, P. The World Bank and Non-Governmental Organizations: The Limits of Apolitical Development; St. Martin's Press: New York, NY, USA, 1995.

86. Watson, N. Collaborative Capital: A Key to the Successful Practice of Integrated Water Resources Management. In Multi-Stakeholder Platforms for Integrated Water Management; Ashgate Publishing: Aldershot, UK, 2007.

87. Pahl-Wostl, C.; Downing, T.; Kabat, P.; Magnuszewski, P.; Meigh, J.; Schlueter, M.; Sendzimir, J.; Werners, S. Transition to Adaptive Water Management; The NeWater Project. NeWater Report Series, No. 1; University of Osnabrück: Osnabrück, Germany, 2004. 
88. Pahl-Wostl, C. Transitions towards adaptive management of water facing climate and global change. Water Resour. Manag. 2007, 21, 49-62. [CrossRef]

89. Kemper, K.E.; Blomquist, W.; Dinar, A. Integrated River Basin Management through Decentralization; Springer: Berlin/Heidelberg, Germany, 2007. 